\title{
Methodological appendix
}

Throughout this study I have combined textual and contextual investigations of documentary forms with qualitative audience research. Each of the various methods of data gathering and analysis employed in this research has its own advantages, weaknesses and consequences. I have directly sought expressions of response from filmgoers via questionnaires designed according to my research concerns and imperatives. I have also drawn on existing materials, such as web postings, whose production has been shaped by a number of influences, but not my own interventions. In between the two poles of these 'solicited' and 'found' viewer statements lies the Mass Observation Archive, a pre-existing forum to which I addressed a specific set of questions. Finally, I have examined my own responses to the two Paradise Lost documentaries, not in order to elevate myself as a viewer more worthy of attention than others quoted in this book, but rather to acknowledge and foreground my own speaking position, which has informed the whole project.

Whatever the particular audience research method in use at any moment, a number of points are pertinent. First, my own decisions and actions, both in research design and the selective interpretation of viewer responses, need to be acknowledged. It is vital that any researcher remain aware of her/his own interventions in producing audience statements as knowable data. This process will include gathering and organising data, often arranging individual respondents into larger groups, and according significance to chosen extracts. I have termed this discursive production of audiences and their activities 'audiencing'. ${ }^{1}$ 
The partial, incomplete and contextually shaped nature of any knowledges produced via audience research should also be recognised. I have already pointed to some examples of this in earlier chapters. But while the chain of decisions involved in audiencing requires self-reflexive examination, care should be taken to avoid losing sight of the purpose of the study and tipping over into critical paralysis and/or the assumption that somewhere over the horizon might lie a source of direct, unmediated access to the 'truth' of audience response. (This is not to argue for a relativist tolerance of any and all research methods as equally compromised or useful, however. It is still possible to make critical distinctions between successful and unsuccessful audience research.) Accordingly, in this book I have paid attention to some of my research choices and their implications while trying to avoid the defeatism born of excessive self-criticism. At the end of this appendix, I have listed questionnaires and relevant sample information for my case studies. In the next two sections, I consider procedures of data gathering and analysis in a little more detail.

\section{Data gathering}

The contingent and performative nature of statements from respondents needs to be confronted. These have inevitably been shaped in part by the various conditions of their production, whether the relevant context is a website forum, archive sample, or a questionnaire handed out at a particular cinema. Consequently, decisions about how to locate - and in some ways produce - an audience sample, and how to gather data from it, become significant.

For instance, Chapter 6, on watching wildlife documentaries on television made use of a questionnaire handed out to 27 sixthformers of various ethnic and class backgrounds from an inner London college, who were taking a short residential course at the campus where I work. This step enabled me to widen the ethnic and social range of respondents discussed, beyond the largely white and often middle-class samples provided by my pilot study and the Mass Observation Archive. The particular social context of this research scenario, namely an educational setting in a university teaching room, and accompanying power relations between myself as an admissions tutor and researcher and the visiting sixth- 
formers, may well have encouraged demand characteristics whereby respondents try to give the 'right answers'. In an attempt to mitigate this, I tried to present the event as an exchange rather than a formal exercise, a chance to swap information (about the University, about viewing habits) that would be mutually beneficial. The success or otherwise of this strategy is ultimately up to the reader to decide, but it is important to register it (and my perception of the need for it) as one small part of the research process. The study also drew on the writings of Mass Observation Archive correspondents, who employed a range of modes of selfpresentation, from the apologetic to those making bids for distinction. An awareness of context-specific and presentational elements such as those discussed here does not invalidate my analyses, but should pre-empt any empiricist claims of straightforwardly accessing some objective truth.

\title{
Data analysis and interpretation
}

On the whole, qualitative audience research tends to devote more attention to self-reflexive consideration of method than many other traditions under the wide rubrics of film studies and media studies. However, as Ann Gray has noted, this self-reflexivity tends to focus more on moments and scenarios of data gathering rather than on the (inevitably intertwined) processes of 'writing up':

\begin{abstract}
Many researchers are now writing about their role and position within the research process, and especially ... in relation to 'field work' of various kinds. However, the ways in which researchers go about organising and analysing their data and research material are rarely discussed. This is strange because, arguably, this is one of the most creative parts of the process where the researcher puts their own unique stamp on the project through their interpretation and analysis. $^{2}$
\end{abstract}

As constituted and made sense of through such necessary processes of interpretation, audience materials can be used to open up dialogues with established understandings and theories. Suggestive discoveries made through audience research may support, confirm or challenge the researcher's prior assumptions, at times demanding that new critical models be proposed. In this way, audience research has the potential to function as an engine powering innovations in critical thinking. The researcher may thus 
become invested in seeking confirmation of a certain premise or hypothesis, or in seeking material that challenges existing paradigms, or may oscillate between these two positions. In any case, it is crucial that the s/he is sufficiently open-minded to view surprise as a positive outcome, and if necessary, to take the trouble to rethink critical approaches and interpretations in response to any such shock thrown up by audience research. This is also an important way of showing respect for people being 'audienced' by the researcher.

Matt Hills's consideration of the contrasting possibilities of confirmation or surprise, developed via his application of Christopher Bollas's notion of the 'aleatory object' to the procedures of audience research, is of relevance here. Hills suggests that:

the encounter of academic Self and respondent Other can itself be considered as an interplay between desire and surprise. That is, the researcher may still hear what he or she wants to, may focus on statements and behaviour that appear to fit into preexistent theoretical frameworks, and may use such statements to support theoretical certainties and orthodoxies ... But certain moments ... may also give rise to material that is not felt to be theoretically prefigured ... To this extent, the ethnographic Other can act as a form of aleatory object for the researcher, where 'the individual uses things while knowing that the aleatory vector is so prominent that he will also be played upon by the object'. ${ }^{3}$

In Chapter 6 I considered the research process in terms of a series of risks and opportunities, when viewed from the perspective of respondents. The same is also true from the researcher's standpoint. Audience research carries the promise of new discoveries, in terms of both novel understandings or knowledges and the means by which to engage with existing theories and debates. However, these prizes are far from guaranteed. One of the disincentives associated with audience studies is the disappointment experienced (or merely feared) when a project leads to little that can be rendered 'useful' or productive. Of course, much of the researcher's (relatively invisible) labour is precisely in forging connections of various kinds between current understandings within the field and new audience data. It is this under-explored labour of 'making use' of audience research via critical interpretation that both Hills and Gray call attention to in the passages quoted above. 
An understandable response to research disappointments is to want to draw a veil over them, rather than admit to mistakes or to a lack of progress or insight. In a rare exception to this general silence, Ellen Seiter writes of a 'troubling interview' at which she found it impossible to build any rapport with two men who were talking to her about their television viewing, or to gain material that she considered usable or relevant. Ultimately, Seiter recuperates this negative experience as the motor for a self-reflexive assessment of the interview as research process and of the power relations which structured it. ${ }^{4}$ I cannot recuperate all my own problems and dead ends quite so effectively here. I have already written in this book about the difficulty of tracking down viewers who have refused to watch, or have never encountered, certain films and programmes. However, one or two other moments in the project have been of rather less utility. Nevertheless, I do still want to acknowledge them as a part of the larger story of this research project.

As in any audience study, I experienced moments of disappointment and thwarted expectations, as well as of surprise and excitement. The latter included the range and depth of responses discovered via the Mass Observation Archive, the Capturing the Friedmans website forum, and questionnaires returned by viewers of Touching the Void. For me, parts of the case study of audience responses to Etre et avoir were rather more problematic, however. I was hoping that this study would deliver more material on issues of class and taste than proved to be the case. In the event, I feel that the chapter works well as a discussion of generic expectations of the documentary mode, and as an initial inquiry into middleclass taste publics. Fortunately, as this was my first study in the project, I also had time to respond by designing and writing another inquiry (now Chapter 5) which made use of autoethnography to extend my consideration of issues of class and/in documentary.

Before moving on to details of the questionnaires used, and audience samples produced, in this study, I want to briefly return to one point raised above: the role of audience statements in catalysing critical inquiry. When audience research is written up, the final format may at times seem to imply that all research questions have been considered, read around, and refined before any engagement with the audience, who simply add the final, illustrative, pieces in the puzzle. This is not in fact the case in the 
current study (nor in my earlier work on audiences for Hollywood fiction films). Of course, in both cases I did have significant initial areas of interest, questions and avenues of inquiry which shaped, among other things, the choice of case study films and television programmes. But, at every subsequent step of the journey, audience responses raised, or newly inflected, such issues in ways that demanded further thought.

In the current study, these instances included discussions of the appeals of France among the Etre et Avoir sample, notions of a portable inspiration attested to by viewers of Touching the Void, engagements with the personal and the political raised on the Capturing the Friedmans website, and a range of attitudes towards mediated and first-hand encounters with the natural world displayed by correspondents in the Mass Observation Archive. The interpretation and analysis of this kind of material required looking further into such issues, reading more, and ultimately, working to accommodate these themes and issues into the structure of each chapter. This last activity may on occasions downplay the vicissitudes of research activity in order to stress the authority and coherence of the final argument presented. In this brief appendix I hope to have redressed the balance slightly by pointing to some of the halting steps taken on the way to producing such 'finished' audience research. 


\section{Etre et avoir questionnaire}

\section{QUESTIONNAIRE}

\section{PART ONE}

*PLEASE ANSWER THE QUESTIONS ON THIS PAGE BEFORE READING THE REST OF THE QUESTIONNAIRE*

1 What were your responses to Etre et avoir?

(please use another page if necessary)

2 Why did you go to see the film?

3 What did you know about the film before watching it? Where did this information come from?

4 What did you like best about the film?

5 What did you like least about the film?

6 How important to your enjoyment was the fact that the film is a documentary?

Please give reasons for your answer.

7 How important to your enjoyment was the fact that the film is French? Please give reasons for your answer.

8 How would you describe the differences between this particular film and a typical fiction film?

9 How would you describe the similarities between this particular film and a typical fiction film?

10 How would you describe the ideal audience for the film?

11 Who did you identify with when watching the film, and why?

12 Did you notice anything about the film's form (over and above its content)? If so, what was your response to this element/s?

13 Are you a regular consumer of documentary films? If 'yes', please say why. If 'no', please say why not.

14 Please list the last three documentaries you watched.

15 How would you define a good documentary film?

16 How would you describe the differences between documentary film (in general) and fiction film (in general)?

17 How would you describe the similarities between documentary film (in general) and fiction film (in general)?

18 Are you a regular consumer of 'reality television'? If 'yes', please say why. If 'no', please say why not.

19 Please list the last three 'reality television' programmes you watched. 
20 How would you define good 'reality television'?

21 Do you trust documentary films to tell the truth? Please give reasons for your answer.

22 Do you trust 'reality tv' to tell the truth? Please give reasons for your answer.

23 What are the last three fiction films that you watched (on tv, video or at the cinema)?

24 What are your three favourite programmes on tv?

25 What radio station/s do you listen to?

26 What are the last three books you read?

27 Please list your six favourite leisure pursuits in order.

Would you include going to the cinema or watching tv on your list?

28 Is there anything else you would like to say, about documentaries or any other issue raised by the questionnaire so far?

\section{PART TWO}

The following questions are entirely about you. I would be very grateful if you could answer them all. However, if you'd rather leave some blank, please do so.

29 First Name:

(please state 'Anonymous', if you wish)

30 Age:

31 Gender:

32 Nationality:

33 Race:

34 Occupation:

35 Education - please tick against relevant heading:

Secondary school - left at 16 (state)

Secondary school - left at 16 (private)

Secondary school - left at 18 (state)

Secondary school - left at 18 (private)

Further education - please give details:

Higher Education:

University degree (BA, BSc etc)

University degree (MA, MSc etc)

36 Do you speak French? 
37 Contact details (these are optional):

Address:

Phone no:

Email address:

38 Would you be prepared to be interviewed for the second stage of the research project =individually? = in a group?

39 Would you be prepared to be quoted in any publication based on this research? (please tick)

Yes - by first name

Yes - anonymously

No

THANK YOU FOR YOUR TIME

\section{Etre et avoir audience sample}

Anon., (1), British, white, female, school counsellor, age 51

Anon., (2), no race or nationality given, male, student, age 30

Anon., (3), French, white, female, senior lecturer, age 44

Anon., (4), British, white, male, entertainment news editor, age 38

Anon., (5), British, white, female, secretary, age 59

Anon., (6), British, white, female, educational psychologist, age 35

Anon., (7), British, white, female, teacher/lecturer, age not given

Anon., (8), British, white, female, nurse, age 52

Anon., (9), British, white, female, teacher, age 45

Anon., (10), British, white, male, student, age 30

Anon., (11), British, white, female, learning and development facilitator, age 50

Anon., (12), British, white, female, occupational therapist, age 28

Anon., (13), British, white, male, teacher and psychotherapist, age 52

Anon., (14), Spanish, white, female, postgraduate student, age 26

Paul, British, white, male, teacher, age 31

Chris, British, white, male, teacher, age 44

Sophie, British, white, female, tacher, age 23

Caroline, British, white, female, student, age 34

Mark, British, white, male, book editor, age 39

John, English, white, male, instructor, age 60

Tim, British, white, male, teacher, age 46

Lynne, British, white, female, teacher, age 51

Kenneth, British, white, male, retired telecomms engineer, age 82 
Mar, Spanish, white, female,research fellow in physics, age 36

Jon, British, white, male, teacher and psychotherapist, age 52

David, British, white, male, teacher, age 36

Bernard, British, white, male, chartered surveyor, age 52

Victoria, British, white, female,teacher, age 29

Haydn, British white, male, Access student, age 29

Cas, British, white, female, teacher, age 51

Anne, British, white, female, home tutor, age 55

Graham, British, white, male, teacher, age 57

Janet, British, white, female, university lecturer, age 52

Pascal, French, white, male, project engineer, age 30

Adrian, British, white, male, journalist, age 34

Roy, British, white, male, retired accountant, age 65

\section{Touching the Void questionnaire}

\section{QUESTIONNAIRE}

PART ONE

*PLEASE ANSWER THE QUESTIONS ON THIS PAGE BEFORE READING THE REST OF THE QUESTIONNAIRE*

1 What were your responses to Touching the Void?

(please use another page if necessary)

2 Why did you go to see the film?

3 What did you know about the film before watching it? Where did this information come from?

4 What did you like best about the film?

5 What did you like least about the film?

6 Did Touching the Void remind you of any other films (or tv programmes)? Please give details

7 If you have read Joe Simpson' book, Touching the Void, how would you compare the book and the film? Do you prefer one over the other? If so why?

8 Do you think anything should have been done differently by the filmmakers?

If so, please give details.

9 How important to your enjoyment was the fact that the film is a documentary?

Please give reasons for your answer.

10 How important to your enjoyment was the fact that the film was based on Joe Simpson's book? Please give reasons for your answer. 
11 Were any other factors important to your enjoyment of the film? Please give details.

12 Do you think this story would have worked as well, better, or less well, as a fiction film? Please give reasons for your answer

13 How would you describe the ideal audience for the film?

14 Who did you identify with when watching the film, and why?

15 The film combines interviews with re-enactments of the climb.

Do you think these two elements combined successfully or not?

Did you prefer one of these elements over the other?

(Please give reasons for your answer)

16 Do you think the film ran into any ethical or moral dilemmas or problems?

(Please give reasons for your answer)

17 Are you a regular consumer of documentary (on film, video or tv)? If 'yes', please say why. If 'no', please say why not.

18 Please list the last three documentaries you watched.

19 How would you define a good documentary film?

20 Do you think documentaries are best suited to the cinema, video, or television, or all three? (Please give reasons for your answer)

21 Do you trust documentary films to tell the truth? Please give reasons for your answer.

22 Do you have any experience of climbing yourself? (If so, please give details)

23 Please list your six favourite leisure pursuits in order.

Would you include going to the cinema or watching tv on your list?

24 Is there anything else you would like to say, about Touching the Void or any other issue raised by the questionnaire so far?

\section{PART TWO}

The following questions are entirely about you. I would be very grateful if you could answer them all. However, if you'd rather leave some blank, please do so.

25 First Name: (please state 'Anonymous', if you wish)

26 Age:

27 Gender:

28 Nationality:

29 Race:

30 Occupation: 
31 Education - please tick against relevant heading:

Secondary school (state)

Secondary school (private)

Further education - please give details:

Higher Education:

University degree (BA, BSc etc)

University degree (MA, MSc etc)

32 Contact details (these are optional):

Address:

Phone no:

Email address:

33 Would you be prepared to be interviewed for the second stage of the research project = individually? = in a group?

34 Would you be prepared to be quoted in any publication based on this research? (please tick)

Yes - by first name Yes - anonymously

No

THANK YOU FOR YOUR TIME

\section{Touching the Void audience sample}

Anon. (1), white, British, male, playwright, age '50s', no climbing experience

Anon. (2), white, British, male, academic, age 45, with climbing experience

Anon. (3), white, British, male, accountant, age 40, no climbing experience

Anon. (4), no details given.

Anon. (5), no details given.

Anon. (6), no details given, some climbing experience

Anon. (7), white, British, female, housing officer, age 45, no climbing experience

Anon. (8), white, British, female, therapist, age 36, limited climbing experience

Anon. (9), white, British, female, yoga teacher, age 51, climbed briefly when younger

Anon. (10), white, British, female, doctor, age 40, mountain walking 
experience

Anon. (11), white, British, male, GP, age 40, some climbing experience

Anon. (12), white, Austrian, therapist, female, age 37, no climbing experience

Anon. (13), British, no race given, male, visual effects artist, age 49, lists walking as a hobby

Anon. (14), British, no race given, female, office worker, age 58, no climbing experience

Anon. (15), British, no race given, male, age 49, no climbing experience

Anon. (16), white, British, female, conference organiser, age 47, some climbing experience

Anon. (17 and 18), mother and son completed questionnaire together, white, British, female, teacher, age 54 and white, British, male, school student, age 16

Anon. (19), British, no race given, male, head of research group, age 54, 'limited' climbing experience

Anon. (20), British, no race given, female, unemployed, age 49, no climbing experience

Anon. (21), white, French, female costumier, age 32, no adult climbing experience

Ben, white, British, male, account director, age 34, no climbing experience Claire, white, British, female, education officer, age 27, indoor climber (Brighton Explorers)

David, white, British, male, mountain guide, age 39

Jack, white, British, male, teacher, age 31, 'a little' climbing experience

Jane, British, no race given, female, public service manager, age 46 , no climbing experience

Janet, white British, female, retired school teacher, age 60 , some climbing experience

Jo, white, British, female, doctor, age 40, general mountain walking

Julia, white, British, female, environmental health officer, age 36, climbs 'a very small amount'

Kim, white, British, female, painter and decorator, age 46, some climbing experience 'as a learner'

Linda, white, British, female, administrator, age 52, non-climber

Martin, white, British, male, cabinet maker, age 27, some climbing experience

Peter, white, British, male, Ph.D. student/painter and decorator, age 37, hill walker

Peter, white, British male, clerical worker, age 38, 'low-level' climber

Phil, white, British, male, signalman, age 40, occasional climber (Brighton Explorers

Zoe, white, British, female, university administrator, age 60 , non-climber 


\section{Mass Observation directive, summer 2005:}

As usual, please start all three parts of your reply on a new sheet of paper with your M-O number, (NOT name), sex, age, marital status, the town or village where you live and your occupation or former occupation.

Remember not to identify yourself or other people inadvertently within your reply.

\section{Part 1:}

The Universe and Outer Space

\section{Part 2:}

\section{Wildlife documentaries}

Your viewing

What was the last wildlife documentary you watched? Was it a film/DVD/ video/TV programme? Why did you watch it? Where did you watch it? Whom did you watch it with? What did you think of it?

How often do you watch wildlife documentaries on DVD, VHS, TV?

Do you usually watch them on your own or with anyone else? Does anyone else in your family or house watch them?

Your opinion

What do you think of wildlife documentaries? Do they appeal to particular groups?

If you had to categorise them, how would you group them?

What makes an enjoyable wildlife documentary? And what makes a bad one? Please give examples.

Do you have a favourite show/presenter/channel for wildlife documentaries?

What do you think we learn from wildlife documentaries?

\section{Part 3:}

\section{The General Election 2005}

\section{Respondents to part 2 of the directive:}

(62 men, 108 women. Information on each respondent appears exactly as supplied)

Men:

A833 Male, 71, married, a son and daughter, Chelmsford, retired architect A3153 Male, 42, married, Paddock Wood, Kent, Bank manager

B 1426 Male age 70, married, living in Bracknell, retired quality engineer 
now working part time as an activities tutor in a boarding school B 1442 Age 82, male married retired, served 43[?] years in aviation. Dur-

ing the war I held a commission in the RAF. Living in Spelthorne B1509 Male aged 76, married, Oxford, retired chartered surveyor B1654 Male pensioner (74), married and living with wife in Rugeley,

Staffordshire. Former editorial manager with a weekly newspaper group publishing in Scotland

B1989 Male, aged 77, retired teacher, widower, living in Tunbridge Wells,

Borough councillor (Liberal Democrat), former county councillor

B2240 Married male aged 84 Cathedral city in the south Retired senior business executive

B2969 54, male, lives in Hastings, married, retired

B3133 Sex - Male. Age - 21. Marital status - Single. Where I live -

Prestwood, Buckinghamshire. Occupation - Computer Games Tester B3227 Gender: male. Age: 38. Marital status: single. Home: Birmingham.

Occupation: University Administrator

B3252 60 y-o social worker married male Stafford

C2256 Male age 56 married resident in Birmingham. Former secondary school teacher, retired 2002 as a result of ill health. Now doing some $\mathrm{p}$ [art time consultancy work for the Royal Meteorological Society and various voluntary activities.

C3006 Male 46 years divorced Gloucester local authority town planner C3086 Male 31 Single Morpeth, Northumberland, Systems engineer

C3143 Male 47 married, Ipswich, management consultant

C3167 Male Single Aged 34 Stoke-on-Trent Warehouse operative

D 1602 Male, 63, single, Wimbledon, retired newspaper executive

D3197 (no information given)

E2977 Male, age 23, single, living in Shropshire, working full-time in a factory making tiles

F2218 Anglo-Caledonian single male, aged 76, retired NHS supplies officer, resident in village of NE England.

F3174 Age 47 lecturer in History $6^{\text {th }}$ form college Live in Wakefield Marital status: single

G2134 Male aged 86 retired civil servant Cheam widower

G2818 Male 50 single teacher Manchester

G3025 Male 42 married Cressbrook, Derbyshire, business analyst for a large, national communications company

G3126 Male aged 64 married Bedford French polisher

G3226 Age 57, married, retired police officer, now working part-time for the National Trust, resident in Swanage, Dorset

H3177 Male 61 Oldham married

H3216 Male married 46 Witham, Essex, primary school teacher

J3248 Male aged 58, Caerleon, Newport, South Wales, information and research manager 
K3125 Male 49 Cheadle Staffs, Humanities teacher retired

L1504 Male 79 yoa married. Ottery St Mary [Devon], retired Administrator

M2854 Male 54 single Wisbech distance learning tutor

M 3118 (no details)

M3190 Male, 46, married, civil servant, living in east Boldon

M3217 Male, 36, single, Stamford, Lincolnshire, Screen printer/engrave/ sign maker

N3031 Male age 55 married Solihull West Midlands Office Worker

P1278 (no details given)

P2034 Male, 78, ex school/music teacher Married Newark, Notts

P2915 Male 46 years old single Kingston Upon Thames teacher

P3135 Male 41 married Guisborough, Yorkshire, local government officer P3209 Male age 65 married Welton, East Yorkshire, artist

R40 Married male retired builder East London

R470 Male, 71 years, retired LGV driver, widower, Basildon

R1418 Male aged 83, widower, retired decorator, Derby

R2065 Married retired 89 formerly administrator of the personal health services in London teaching district Mitcham Surrey

R2 143 Male 83 years old married to the same wife for 57 years dwelling in Hythe, Hampshire, since retirement 18 years ago a retired chartered engineer ... working ... around the world.

R3032 Male, aged 63, married, Cardiff, retired civil servant

R3198 Aged 56, Caucasian male. Married with three 'children' all at University in England ... retired in 2004 as a business development director of a 'top three' pharmaceutical company ... B.Sc., Ph.D., D.Sc (Medicine) - all London University. Currently spending 2 weeks in Spain where we have a house.

S2083 Male age 74, married Kingston, Lewes, East Sussex, semi-retired part-time book-keeper

S2246 Age 82 Male Widower Northampton Retired engineer/teacher

S3035 I am a 58-year-old retired banker ... I took early retirement at the age of 50 and haven't regretted it for a moment. I am currently a parttime student studying for a BA in Landscape Studies at Sussex University ... I am married with two grown up daughters, and three grandchildren.

S3071 Male year of birth 1967 Aberdeen chartered surveyor

T3076 Male single 38 Melling, Liverpool Writer/PhD student/Digital TV tester

T3094 Male 34 married Macclesfield (Cheshire) analytical chemist

T3129 Male 36 single Great Somerford Wilts Army officer

V3091 Male 42 Cheltenham journalist

W565 male 78 years of age. Married. Herne Bay Kent Retired, Farmer

W1382 Male age 81 married retired technical writer Weston-super-Mare 
W1893 b.1924. Male. Grew up in the Wirral ... Retired 1983 after 43 years with the same company - as Seignior Production Manager in large food factory ... Lived in various locations in U.K. and Republic of Ireland. Now in Felixstowe. Have never voted Tory.

W3176 [Male] retired teacher widower, aged 64, living in Greenfield, Saddleworth

W3199 Sex: male, age: 16, marital status: single, occupation: student town: Barnstaple

Women:

A1292 grandmother $\mathrm{p} / \mathrm{t}$ teacher Croydon 72 years

Al706 Female married ward clerk // artist Shoreham by Sea

A2801 I am female 39, single, living in York. Unable to work due to a long-

term illness - I have had M.E. for nearly 17 years. Previously, I was training to be a solicitor.

B86 Female, 82, E. London, library asst., housewife

B89 Female aged 74 divorced Leighton Buzzard retired typist

B736 Female

B 1771 Female age 69 married, Mitcham, Surrey, retired secretary

B2810 Female divorced 38 Todmorden

B3170 Male 23 single Wrexham administrator

B7867 Female, married, Barnstaple, retired secretary PA

B 1180 Female 67 southcoast

B 1215 Female 52 years, married +2 children $\mathrm{p} / \mathrm{t}$ recruitment advisor Plymouth

B 1475 Female, 62, single, Chesterfield, retired auditor

B1898 Female, 73, married, Tunbridge Wells, formerly claims advisor, beauty consultant, etc. Now writing short stories.

B2154 Retired radiographer (therapy), single, female, aged 72. Small Cotswold town.

B2065 F married Staines Middx ex civil servant age 733 children 4 grandchildren

B3019 Female, aged 38, single, living in the Isle of Man, civil servant, specialising in Government pension schemes

B3154 Female, 42 years old, married. Stoke on Trent. Money advisor.

B3185 Female, 38, married, Sheffield, Homemaker

B3220 Female, 38 years old, divorced, Kentallen, post office clerk

C41 Female 46 single Shetland single parent

C108 Female, 60 years, widow, RC, 3 stepsons, 1 son, retired, suburbs

C1191 Female age 50 divorced carer Limavady

C1786 Female age 55 married village in Bucks School secretary

C2053 Female, aged 51, married, chartered librarian, now a self-employed

clerical worker, living in Attleborough.

C2078 Female 61 married Odiham 
C2654 Female 62 married Birmingham retired adult education teacher

C2677 Female 53 married Lackock teaching assistant

C2888 Married female age 49 local government officer from Portslade, East Sussex

C1713 Female 56 yrs married Preston receptionist

C2091 Female 65 retired public librarian Eastbourne

C3038 Female 32 single London VT editor/videotape operator (television)

C3210 [no details]

D156 I am a married mum of three. I live in the south east of England. I was born in 1952, married in 1971, my children were born in 1972, 1976 and 1980. I am the manageress of a florist shop and I have 4 grandchildren...so far. D826 F aged 54, married, living in Bristol. Part-time social worker

D966 Female, aged 78, living in London, divorced/ Retired from work in a Citizens Advice Bureau, but still there as a volunteer receptionist; also a part-time minute taker at meetings.

D2585 Female - early 60s Nr Bristol - married 38 years 'children' now 37 and 34 (both still single!) 20 years work as Secretary in large aeroengine company Now P/T clerical at local hospital.

E124 Retired spinster headmistress, born 1924 East Lancs village was long term resident of Gtr Manchester town

E743 Female, born 1951 in Yorkshire. Married, living in Warrington, Cheshire. Part-time teacher of Special Needs in large comprehensive school. One husband, two adult children, two step; children, one cat.

F1560 Female, widow, retired, 84

F1589 F. born $1932 \mathrm{Nfk}$ retd SRN 3 children family bizs [unreadable] firearms. Lives N Staffs

F3137 Female age 36, married, Mulbarton, Norfolk, researcher

G226 Married female age 64. Retired counsellor /therapist Living Fylde coast, N.W.England.

G1041 Female, 79, married, Purley, retired librarian

G3187 Female age 35 Southport Staff nurse

G3201 Female age 40, married, village Aberlemno Occupation: practice manager

H260 Married lady - age 75 - ex-shop manager Brentwood Essex

H266 Widow, 82, living happily in small Lincs town, many interests, USA, NWR Painting, writing, people, holidays, etc

H1703 58 year old female HR assistant married Derbyshire

H1705 Married female 54 Part time word processor operator/amateur artist St Helier, Jersey

H2410 Woman, aged 75, married ex Grammar school teacher, at present living in small North Yorkshire village

H2418 Female 53 single London reception/information worker 
H2673 Female aged 65 widowed living London Docklands Working p/t Librarian

H2639 Female (married) aged 64 years library assistant (retired) housewife - Ipswich Suffolk

H291 1 Female 40 years of age married Herstmonceux special needs assistant

I3189 Female 39 yrs, married

J1407 Widow, 80 London and LOW[?]

J2891 I am a 40 year old married woman with two children/ I have changed career from Occupational therapy to administration and have been doing volunteer work and courses to improve my skills. I am working part time temporarily in a HE College. I live in N Wales but I am not Welsh.

K798 54 year old married female; part-time student and writes, living Norfolk

L1625 F 83 single Grantham retired teacher

L1991 Female 68 years widow Brighton retired nurse/civil servant

L3253 Female 54 years married, Grimbsy housewife

M348 Writer, single, aged 75, SE England

M388 Female, 74, married retired lecturer live in Norfolk market town

N399 70 yr old mother grandmother, widow. Former nurse, former hos-

pital clerical officer, living east London BSc Hons (Open) Dip H\&SW.

Retired due to ill health but now Author and writer.

M1201 Female 42 yo married Chester le Street housewife

M1395 Female, age 75 Divorced Cobham, Surrey formerly CAB adviser M1571 Female age 74 married West Sussex village retired subpostmistress M2164 F 78 widow retired biologist Essex village

M2290 Female, 76, married Glos village, ex journalist

M2629 F 77, married Bristol formerly tutor in adult education

M3055 Female 30 single London compliance manager

M3132 I am female, 42 (born August 1963), married and living in

Linlithgow in the county of West Lothian in Scotland. I am a personal

finance journalist and am also working on my first novel. I'm writing this on Friday, August 12, 2005.

M3147 Female 45 married husband, daughter 19, son 12, father in law, Conwy, shopkeeper

M3202 Married female Penymyndydd, Nr Chester 39 Snr prescribing support technician

N403 Female 68 years widow Pampisford[?] retired part time cleaner

N3212 Female, 29, married, Accrington, law librarian.

N3181 Female unmarried with long term partner 30 Leeds librarian

P1009 Female 65 married Aberystwyth

P1282 Female age 67 married, Lichfield Staffs, BA Humanities, retired, carer for two grandchildren 
P1326 Female, married, aged 67, retired civil servant, living in a rural location near Bath with husband and dogs, with a large garden full of weeds and birds and wild creatures!

P1796 Female 59 part time consultant live in Dorset, married

P2138 Female born 1920s married Chorley, Lancs statistician (retired)

P2546 Woman, 80, married. Village near Hereford, retired social work manager

P2819 Female, age 40, married, from a country town, doing secretarial work.

P3213 Female married Dwygyfylchi

R860 Female married 1 son 57 yrs old South Cheshire retired hairdresser - lecturer - J.P. I still give talks with ladies groups

R1025 62 year old housewife, formerly book-keepr, living in Milton Keynes R1227 F, 61, married, village near Exeter, primary school teacher.

R1468 F. 82. Rtd Eng Insp R.R Derby. Widow.

R1760 Female aged 75 widowed resident SW Essex retied civil servant R2144 Female age 69 married, Birmingham resident, retired teacher S1399 Female 56 married Tunbridge Wells no job

S2220 Fem. Widow German born/bred. Brit. Since 1947, in wee Scot. town, retired Headteacher

S2581 Aged 54 retired bursar Mirfield

S3179 Female 26 living with partner Stockport PA

S3188 Female 39 married Scunthorpe housewife

S3223 [no details]

T1411 Female 83 years widow retired teacher

T1843 Female caseworker separated, 56, Disley

T2543 Female, 71, single, retired library asst, Dudley west Mids.

W563 F retired $\mathrm{m} / \mathrm{o} \mathrm{h} / \mathrm{w}$ tho' not Welsh lives in Welsh village and $\mathrm{v}$ happy here tho' alone.

W571 Female aged 67 married ex-sales assistant 1 daughter, 2 teenage grandsons. Cottingley, nr Bingley, West Yorkshire.

W632 Female/63/widow/Southwick W Sussex

W633 Female, married, 62. Journalist North-East England. One adult daughter, not living at home

W729 Age 48 female, married, supply teacher

W2107 F 64 divorced Ely museum asst

W2244 F married 76 years retired teacher/careers hamlet in small $\mathrm{N}$ town. W2338 Retired female married teacher age 72 village near York

W3163 Female. 47. Co-habiting. Bacup, Lancashire. Wages clerk.

W3233 Female, 25, single, Woodhall Spa, part time sales assitant - full time student

Y2926 I am a married woman of 47, with 2 children, living in Horsham and working at the local Hospital 


\section{Notes}

1 Austin, Hollywood, Hype and Audiences, p. 68.

2 Gray, Research Practice for Cultural Studies, p. 147. See also Ien Ang, 'Wanted: audiences. On the politics of empirical audience studies', in Ellen Seiter, Hans Borchers, Gabriele Kreutzner and Eva-Maria Warth (eds), Remote Control: Television, Audiences and Cultural Power (London, Routledge, 1989), p. 105: 'it is only through the interpretative framework constructed by the researcher that understandings of the "empirical" come about'.

3 Matt Hills, 'Patterns of surprise: the "aleatory object" in psychoanalytic ethnography and cyclical fandom', American Behavioural Scientist, 48:7 (2005), p. 808, quoting Christopher Bollas, Being a Character: Psychoanalysis and Self Experience (London, Routledge, 1993), p. 37.

4 Seiter, 'Making distinctions in tv audience research', pp. 61-84. 